(2) Open Access Full Text Article

REVIEW

\title{
Investigational new drugs in the treatment of inflammatory bowel disease: a review
}

\author{
This article was published in the following Dove Press journal: \\ Journal of Experimental Pharmacology \\ 25 February 201I \\ Number of times this article has been viewed
}

\section{Imogen Williams \\ Jason Goh}

GI Unit, Queen Elizabeth Hospital Birmingham, Edgbaston, Birmingham, England, UK
Correspondence: Jason Goh

GI Unit, Queen Elizabeth Hospital,

Edgbaston, Birmingham,

England BI4 2TH, UK

$\mathrm{Tel}+4401216272000$

Fax +4401216277827

Email jason.goh@uhb.nhs.uk

\begin{abstract}
The unraveling of the immuno-pathobiology of inflammatory bowel disease (IBD) in the past three decades has ushered in a new era of translational medicine. The biotechnology revolution has resulted in a paradigm shift in how clinicians view and treat IBD. Anti-tumor necrosis factor (TNF)- $\alpha$ strategies using infliximab and adalimumab currently dominate the therapeutic arena. Better understanding of how these biologicals work is driving the quest for loftier therapeutic goals of achieving mucosal healing, sustaining deep remission, and even modifying the natural history of IBD. However, not all patients respond to anti-TNF drugs. Immune-mediated adverse reactions and loss of efficacy with time also limit their use. There are many investigational drugs undergoing active clinical trials. Many have not fulfilled their early promises but some are potentially making the transition from bench to trial and to the bedside in the near future. Clinicians and investigators need to underpin our excitement with caution for the unknown long-term consequences of modulating cytokines and selective adhesion molecules in human. Here we provide an overview of investigational new drugs and other therapeutic strategies currently undergoing clinical trials in IBD.
\end{abstract}

Keywords: IBD, infliximab, adalimumab, anti-TNF, Crohn's disease, ulcerative colitis, biological therapy, vedolizumab, ustekinumab

\section{Introduction}

Inflammatory bowel disease (IBD) is estimated to affect about 250,000 individuals in the United Kingdom, predominantly persons under the age of 60. Traditionally, IBD was considered primarily a disease of developed countries; however, the incidence in developing countries, such as India and China, is rising. Prior to the 1950s, there was no truly successful treatment for IBD. The advent of corticosteroids and sulphasalazine in the 1950s and thiopurines in the 1960s dramatically changed the outlook of patients with IBD. ${ }^{1}$ Indeed, the three classes of drugs (mesalazine, corticosteroids, and thiopurines) have retained their place as mainstays of IBD therapeutics today.

The 'biotechnology revolution', spearheaded by anti-tumor necrosis factor (TNF) monoclonal antibodies, marked a new chapter in IBD therapy. This was made possible by the perfect timing of both a comprehensive elucidation of the pathophysiology of IBD and advancement in biotechnology in the past two decades. A dysregulated immune system, along with a genetic predisposition and environmental triggers, is thought to be key to the development of IBD. Modern IBD therapeutic strategies are aimed at modulating the gut adaptive and, to a lesser degree, the innate immune response to downregulate inflammation. These strategies range from being targeted (antagonism 
of specific cytokines or chemokines) to a more global approach (pharmabiotics, stem-cell transplant, leukopheresis, helminths, etc).

\section{Targeting cytokines}

Targeting cytokines to interrupt the immune cascade prevent their proinflammatory effect, and subsequent leukocyte recruitment is an attractive option, and there are many cytokines involved (see Figure 1).

The initial wave of biologic therapies has been directed towards TNF- $\alpha$. This is a proinflammatory cytokine which is central in the pathogenesis of Crohn's disease. ${ }^{2}$ Infliximab is a chimeric monoclonal antibody directed against TNF- $\alpha$ that was introduced into clinical practice in the USA about 12 years ago. ${ }^{3}$ There are now two additional anti-TNF molecules in clinical use: adalimumab and certolizumab pegol; and another (golimumab) currently undergoing Phase III testing. ${ }^{3,4}$ Anti-TNF agents have been shown to induce apoptosis in peripheral blood mononuclear cells and intestinal T cells; however, the exact effects of anti-TNF therapeutics are not completely understood at the molecular level. ${ }^{5}$ They are effective in inducing and maintaining remission in inflammatory and fistulizing Crohn's disease. In the United Kingdom, the National Institute for Health and Clinical Excellence (NICE) have recently issued updated guidelines on the clinical use of infliximab and adalimumab. Despite the revolutionary nature of their clinical efficacy, there remain many unmet needs in IBD therapy and alternatives to TNF-antagonism are highly desirable.

Active immunization is an attractive novel strategy in treating autoimmune diseases and the TNF- $\alpha$-kinoid immunotherapy platform, made possible by Neovacs, is being evaluated in TNF-driven inflammatory diseases. This has the added advantage of avoidance of anti-antibody production. Data from an open-labeled study of TNF-kinoid

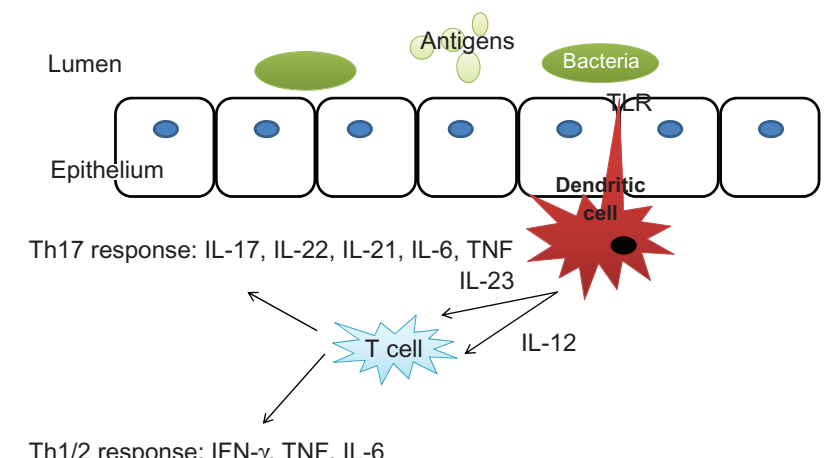

Figure I The cytokine cascade in inflammatory bowel disease.

Abbreviations: IFN, interferon; IL, interleukin; Th, T helper; TLR, Toll-like receptor; TNF, tumor necrosis factor. demonstrating efficacy in Crohn's disease has been presented at the Digestive Diseases Week in May 2010, and a Phase II study is underway. ${ }^{6}$

Interleukin (IL)-6 is secreted by lamina propria T cells and macrophages and activates the T helper (Th) 17 response. ${ }^{7}$ Tocilizumab is a humanized monoclonal antibody that blocks both the membrane-bound and the soluble IL-6 receptor. The results of the first clinical trial are promising: $80 \%$ of the patients with Crohn's disease given tocilizumab infusions biweekly for 12 weeks showed a significantly higher response rate than the placebo group. ${ }^{8}$ Interestingly, there is also growing experimental data that suggest a role for IL-6 not only in chronic inflammation, but also in inflammation-associated tumor development as seen in patients with IBD. ${ }^{9,10}$ Therefore, targeting IL-6 in patients with IBD might not only reduce inflammation but may potentially prevent the development of colitis-associated cancer. Currently tocilizumab is in clinical use treating rheumatoid arthritis and Castleman's disease and is under development with a view to potentially using it in IBD in the future. Although no clinical trials are currently underway, there is a need for a randomized controlled trial evaluating this therapy in patients with IBD.

The IL-12 family of cytokines which includes IL-12 and IL-23 are recognised to play a role in regulating T-cell immune responses. ${ }^{11}$ Both of these cytokines (IL-12 and IL-23) are heterodimers and share an identical subunit (p40). In the case of IL-12, p40 builds a heterodimer with the subunit p35, and in the case of IL-23 p40 builds a heterodimer with the subunit p19. Both have been implicated in murine models of Crohn's disease. ${ }^{12-14}$ Ustekinumab is a human $\operatorname{IgG} 1 \kappa$ monoclonal antibody that binds to the shared p40 subunit of IL-12 and IL-23. This inhibits IL-12 or IL-23 interactions with the cell surface and therefore prevents IL-12- and IL-23-mediated signaling cascades. Ustekinumab has been examined in a Phase IIa trial of patients with moderate to severe Crohn's disease who have failed conventional or anti-TNF therapy. ${ }^{15}$ This showed increased response rates, which were greatest in patients who had previously received anti-TNF treatment with infliximab. Therefore anti-IL-12 p40 treatments might pose an interesting alternative for patients who have previously received anti-TNF treatment, and a Phase IIb trial is currently underway. It remains inconclusive, however, whether the effects observed are mediated via effects on the IL-12 or the IL-23 pathway. Another anti-IL 12/23p40 monoclonal antibody, briakinumab has been shown not to be effective for induction or maintenance of remission in moderate to severe Crohn's disease. ${ }^{16}$ In addition to the above mentioned cytokines, targeting the signal transduction 
of other cytokines in human IBD has been evaluated, but many have not successfully translated into clinical use. These included attempts to modulate interferon- $\alpha,-\beta$ or $-\gamma$, IL-10, and IL-2., ${ }^{3,17}-23$

\section{Selective anti-migration (SAM) strategies}

Currently, some of the most promising new therapies for IBD are directed against small adhesion molecules. Movement of immune cells through the intestinal mucosa is important in health for gut homeostasis. It allows antigen sampling and the development of tolerance to bacterial and food antigens. ${ }^{4}$ This process relies on the movement of leukocytes up a concentration gradient of chemokines secreted by epithelial cells. ${ }^{4}$ Firm adhesion is the last step before leukocyte diapedesis through endothelial pores into the lamina propria of inflamed tissue. Cellular adhesion molecules, therefore, play a critical role in the pathogenesis of IBD, allowing infiltration of T-lymphocytes into the gastrointestinal (GI) tract. Upregulation of these adhesion molecules on the surface of activated lymphocytes and also epithelial cells results in an increased infiltration of activated cells and consequently in an aggravation of the inflammatory process. ${ }^{24}$ Blocking this process presents an exciting therapeutic opportunity in inflammatory conditions.

Leukocyte adhesion to endothelial cells is a multistep process that involves interaction of several adhesion and signaling molecules on the surface of T lymphocytes with their corresponding ligands on the endothelium. Alpha-4-integrin is a selective adhesion molecule expressed on lymphocytes that facilitates adhesion and subsequent leukocyte migration into areas of inflammation. The $\alpha 4 \beta 7$ integrin mediates the infiltration of the GI tract specifically, via binding to mucosal addressin cell adhesion molecule 1 (MAdCAM-1) on endothelial cells ${ }^{25}$ (see Figure 2).

Inhibition of integrins has been proven from animal studies to help in mucosal healing and reduce inflammation. ${ }^{26,27}$

The first of the new class of selective adhesion molecule inhibitors is natalizumab. It is a recombinant humanized $\mathrm{IgG}_{4}$ monoclonal antibody to the $\alpha 4$ integrin subunit that blocks adhesion and subsequent leukocyte migration. ${ }^{27,28}$ Natalizumab, via its nondiscriminant blockade of systemic $\alpha 4$ integrin, is linked to the development of the progressive fatal infectious disease, progressive multifocal leucoencephalopathy (PML). Natalizumab was suspended in March 2005 because of serious adverse events (including PML) in patients affected by multiple sclerosis and treated with a combination of natalizumab and interferon- $\beta-1 \mathrm{a}$ and in one Crohn's

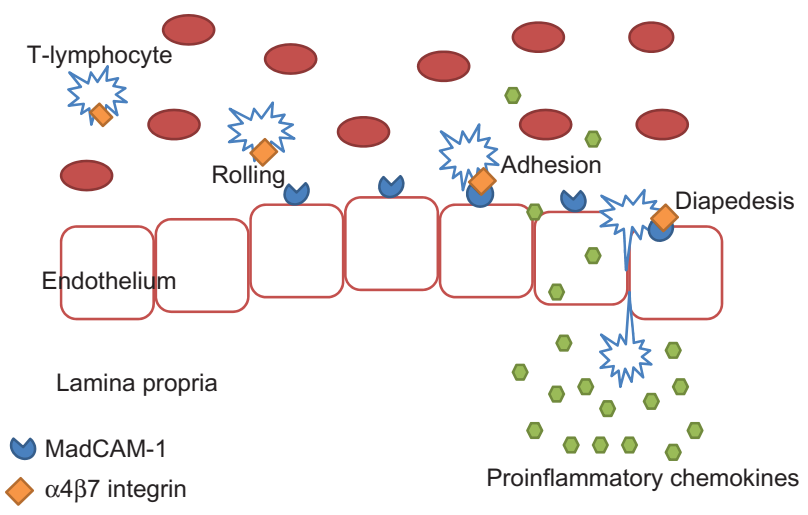

Figure 2 Migration of immune cells to the site of inflammation in the gut. Abbreviation: MadCAM-I, mucosal addressin cell adhesion molecule I.

disease patient treated with natalizumab monotherapy. ${ }^{29,30}$ It is now only available through restricted prescribing for multiple sclerosis.

More promising is vedolizumab, a recombinant humanized $\mathrm{IgG}_{1}$ monoclonal antibody which inhibits only gut-specific MAdCAM-1-mediated leukocyte adhesion by binding to the $\alpha 4 \beta 7$ integrin on peripheral blood lymphocytes and inhibiting adhesion of these 'gut-homing' lymphocytes to MAdCAM- $1 .{ }^{3}$ Targeting $\alpha 4 \beta 7$ integrin theoretically confers gut specificity for vedolizumab. $\alpha 4 \beta 7$ integrin is thought to be specific to CD4+ memory cells, which are pathogenic in IBD. ${ }^{31,32}$ Therefore, vedolizumab specifically targets the CD4+ memory subpopulation that is pathogenic in IBD while sparing other CD4+ memory subpopulations and monocytes that are integral for immunosurveillance and host defense. Data from a Phase II clinical trial of patients with colitis suggest that vedolizumab may be effective for induction of clinical response and remission in patients with moderately severe ulcerative colitis and also in patients with moderately active Crohn's disease. ${ }^{33,34}$ Phase III trials in ulcerative colitis and Crohn's disease are currently underway.

Another antimigration therapy would be to target chemokine receptors, eg, chemokine receptor 9 (CCR9), to prevent leukocyte recruitment to the site of inflammation. The Phase II/III PROTECT-1 trial looked at a new orally available CCR-9 inhibitor, Traficet-EN" ${ }^{\mathrm{TM}}$ (GSK-1605786 or CCX-282). ${ }^{35}$ CCR9 is a chemokine receptor central for migration of immune cells into the intestine. Inhibition of CCR9 by Traficet-EN may inhibit B- and T-cell entry to the small gut and ameliorate inflammation, while leaving immune function at other anatomical sites unaffected. Data from PROTECT-1 suggests that GSK-1605786 is efficacious in patients with Crohn's disease, with the advantage of being orally bioavailable. Other antimigration strategies 
currently being tested include: anti- $\beta 7$ monoclonal antibodies in ulcerative colitis and anti-MAdCAM-1 antibodies in ulcerative colitis. ${ }^{4}$ Further data on efficacy and potential adverse effect on gut homeostasis are awaited. Drugs currently in development for use in IBD are summarized in Table 1.

\section{Targeting T- and B-lymphocytes}

Blocking T-cell receptors is thought to induce short-term T-cell apoptosis or reduced response to cytokines and therefore amelioration of disease. Reagents blocking the CD4 T-cell receptor have been found to cause long-term depletion of lymphocytes in some patients and have limited clinical potential. ${ }^{36}$ In general, strategies directed against naïve T-cells have been disappointing in IBD.

Visilizumab, an anti-CD3 monoclonal antibody did show promising results in Phase I and II trials. Disappointingly, a Phase III study in subjects with intravenous steroid refractory ulcerative colitis was withdrawn due to interim analysis showing parity in colectomy rates in both visilizumab and placebo groups and poor tolerance of the drug. ${ }^{37}$

Basiliximab, a chimeric $\operatorname{IgG}_{1}$ monoclonal antibody directed against the $\alpha$-chain of IL-2R (CD25), showed good initial results in an open-labeled study and seemed to exert a steroid-sensitizing effect. Repeated infusions seem to promote the development of human anti-chimeric antibodies that may limit its clinical use. ${ }^{18}$ Daclizumab, a humanized IgG1 monoclonal antibody against CD25, has shown no efficacy. ${ }^{38}$

More recently, Abatacept, a CTLA-4 fusion protein that is effective in rheumatoid arthritis, has not fulfilled its therapeutic promise in a Phase III study in Crohn's disease unveiled at the Digestive Diseases Week in 2010. ${ }^{39}$ There is currently no convincing case to support B-cell depletion strategy in IBD. Indeed, treatment with rituximab has been linked to exacerbation of ulcerative colitis. ${ }^{40}$

\section{Probiotics and prebiotics}

The gut flora microenvironment is increasingly recognized as a key contributor to gut health and perturbation of this symbiotic relationship has been implicated in many GI diseases including irritable bowel syndrome, GI infections and IBD. Major investment in manipulation of these microbes to restore gut health represents a burgeoning industry undeterred by the complexity of the science behind it and multiple false starts, and one sustained by much excitement and hope.

Probiotics have been defined as 'a preparation of a product containing viable, defined microorganisms in sufficient

Table I Selected biological therapy trial update

\begin{tabular}{|c|c|c|c|c|c|c|}
\hline Drug & $\begin{array}{l}\text { Mechanism } \\
\text { of action }\end{array}$ & $\begin{array}{l}\text { Development } \\
\text { status }\end{array}$ & $\begin{array}{l}\text { Published IBD } \\
\text { studies }\end{array}$ & Trials underway & $\begin{array}{l}\text { Number of } \\
\text { patients treated }\end{array}$ & $\begin{array}{l}\text { Significant } \\
\text { results }\end{array}$ \\
\hline Golimumab & Anti-TNF $\alpha$ & Phase II/III & $\begin{array}{l}\text { Nil published on IBD. } \\
\text { Extensive evidence } \\
\text { for use in rheumatoid } \\
\text { arthritis, psoriatic } \\
\text { arthropathy, ankylosing } \\
\text { spondylitis }\end{array}$ & $\begin{array}{l}\text { Induction and } \\
\text { maintenance therapy } \\
\text { in patients with } \\
\text { moderately to severely } \\
\text { active ulcerative colitis }\end{array}$ & Studies recruiting & \\
\hline Tocilizumab & $\begin{array}{l}\text { Anti-IL-6 } \\
\text { receptor }\end{array}$ & Phase II & Ito et $\mathrm{al}^{8}$ & $\begin{array}{l}\text { No trials underway } \\
\text { at present }\end{array}$ & $\begin{array}{l}36 \text { patients with } \\
\text { Crohn's disease }\end{array}$ & $\begin{array}{l}80 \% \text { clinical } \\
\text { response; } \\
20 \% \text { remission }\end{array}$ \\
\hline Ustekinumab & Anti-IL-12/23 & Phase II & Sandborn et $\mathrm{al}^{15}$ & $\begin{array}{l}\text { Moderately to severely } \\
\text { active Crohn's disease, } \\
\text { previously treated with } \\
\text { anti-TNF therapy }\end{array}$ & $\begin{array}{l}\text { I04 patients with } \\
\text { Crohn's disease }\end{array}$ & $\begin{array}{l}59 \% \text { response in } \\
\text { patients previously } \\
\text { treated with } \\
\text { anti-TNF- } \alpha\end{array}$ \\
\hline Vedolizumab & $\begin{array}{l}\text { Anti- } \alpha 4 \beta 7 \\
\text { integrin }\end{array}$ & Phase III & Feagan et $\mathrm{al}^{34}$ & $\begin{array}{l}\text { Induction and } \\
\text { maintenance in patients } \\
\text { with moderately to } \\
\text { severely active Crohn's } \\
\text { disease, ulcerative } \\
\text { colitis, and open labeled } \\
\text { observational study } \\
(\text { GEMINI I/2/3) }\end{array}$ & $\begin{array}{l}\text { I } 27 \text { patients with } \\
\text { Crohn's disease }\end{array}$ & $\begin{array}{l}37 \% \text { remission } \\
\text { in higher dose } \\
\text { treatment group }\end{array}$ \\
\hline TNF-kinoid & Immunotherapy & Phase I/II & Rogler et $\mathrm{al}^{6}$ & $\begin{array}{l}\text { Phase II in patients with } \\
\text { moderate/severe } \\
\text { Crohn's disease }\end{array}$ & $\begin{array}{l}\text { I3 patients with } \\
\text { Crohn's disease }\end{array}$ & \\
\hline
\end{tabular}

Abbreviations: IBD, inflammatory bowel disease; IL, interleukin; TNF, tumor necrosis factor. 
numbers, which, when administered in adequate amounts, alters the microflora in a compartment of the host and by that, exert beneficial effects in the host' ${ }^{41}$ Probiotics are postulated to exert several protective effects possibly by secretion of antibacterial substances, adjusting the gut immune response to commensal bacteria, prevention of colonization by intestinal pathogens, and the stimulation of anti-inflammatory cytokine production. ${ }^{42}$ Prebiotics are nondigestible (oligo) saccharides, defined as 'selectively fermented ingredients that allow specific changes, both in the composition and/or activity of the gastrointestinal microflora that confers benefits upon host well being and health' ${ }^{43}$ Prebiotics reach the colon undigested, where they are metabolized by commensal bacteria into short-chain fatty acids (SCFAs) and lactate. The potential protective mechanisms of prebiotics are still not clear but are thought to be related to changes in the composition of the intestinal microflora brought about by selective stimulation of the growth of commensal protective bacteria, ${ }^{43-46}$ and amongst other things, an increase in SCFAs which have a central role in the lifecycle of colonocytes. ${ }^{47}$ Although the theory is attractive and logical, as yet there is no evidence to support the routine use of prebiotics or probiotics in IBD. There is, however, some data to support their use in pouchitis and potentially in the maintenance of remission in ulcerative colitis. ${ }^{48-51}$ This is an exciting area that will continue to evolve in the coming years.

\section{Worms}

As mentioned previously, the development of IBD probably results from an overly vigorous immune response to the contents of the bowel lumen. Environmental factors clearly play a role as supported by the reduced incidence of ulcerative colitis in patients who have undergone appendicectomy, increased risk of Crohn's disease in smokers, and the striking geographical variation in the incidence of IBD. ${ }^{52-56}$ Risk is increased with a shift to a more affluent lifestyle.

There is epidemiological evidence to support a role for helminths in protection from IBD. ${ }^{57}$ The rates of IBD are inversely related to the rates of infestation with worms globally. Helminths are recognized to induce immune tolerance in the host, and there is murine evidence that infection with certain helminths may protect from the development of IBD and other immune-mediated conditions. ${ }^{58,59}$ There were some human studies looking at the use of helminths in IBD which showed some improvement in symptoms, but the results were not statistically significant. ${ }^{60,61}$ The jury is still out on its future as a therapy. Larger clinical trials are needed and ways of improving acceptance by patients are being devised.

\section{Leukopheresis and autologous stem cell transplant}

Invasion of the intestinal mucosa by activated leukocytes is characteristic of IBD. Therefore, removal of circulating leukocytes is a reasonable approach for treating IBD. Leukopheresis, using a selective adsorption apheresis device with a column of polyethylenephtarate fibers that captures monocytes, granulocytes, and lymphocytes, has been used to treat ulcerative colitis in Japan and Europe..$^{62} \mathrm{~A}$ recent study in Japan has shown a good response rate but is limited by the short follow-up period and absence of randomization and data on sustained response rates. ${ }^{63}$ Another sham-controlled study of apheresis in ulcerative colitis found no difference in response or remission rates. ${ }^{64}$ Further studies are needed to evaluate its efficacy, cost-effectiveness, and comparison with biological therapy.

The potential of stem-cell transplant (SCT) as a treatment option for Crohn's disease arose following fortuitous observations that patients with IBD had dramatic improvement in their symptoms following high-dose chemotherapy or SCT for another diagnosis. Both high-dose chemotherapy and hematopoietic SCT are being explored as potential treatments for IBD and other autoimmune diseases. The exact mechanism by which high-dose immunosuppression or stem cells 'reset' the immune system and provide remission for these diseases is not yet clear. Results from the few animal studies are positive, and multi-center human studies are currently ongoing. . $5,66^{6}$

\section{Antibiotics}

Leading the plenary session at the United European Gastroenterology Week in October 2010 was the study of rifaximin in Crohn's disease. This was a placebo-controlled trial of 12-week therapy using an extended intestinal release formulation of rifaximin, an antibiotic that has low bioavailability, in moderately active Crohn's disease. Optimal efficacy was demonstrated for $800 \mathrm{mg}$ b.d. dosing with statistically significant benefit over placebo both in inducing clinical remission (Crohn's disease activity index to less than 150) and maintaining remission in the 12-week follow-up period following cessation of active treatment. ${ }^{67}$

\section{Conclusion}

Classical models of chronic inflammatory diseases such as IBD have benefited greatly from the unprecedented strides made in translational medicine in the past decade. What has underpinned the development of new drugs is a paradigm shift in the way we approach treatment of the 
patient with IBD: the shift toward a time-bound, close to top-down strategy; the shift away from 'steroid-after-steroid' and a passive 'laisser faire' mindset; our increasing awareness of and vigilance toward infective and neoplastic sequelae of increasingly powerful treatment; and the increasing role of a multi-disciplinary team in the overall management of the patient. Professional bodies sub-specializing in IBD such as the European Crohn's and Colitis Organisation (ECCO) will play an increasing role in promoting collaborative research and education, disseminating new ideas and setting standards for best practice in IBD. With ongoing developments in new drugs, we can aim toward a bespoke and individualized treatment strategy as we continue to gain better understanding of IBD genotypes and phenotypes.

\section{Disclosure}

The authors report no conflicts of interest in this work.

\section{References}

1. Bean RH. The treatment of chronic ulcerative colitis with 6-mercaptopurine. Med J Aust. 1962;49(2):592-593.

2. Van Deventer SJ. Tumour necrosis factor and Crohn's disease. Gut. 1997;40:443-448.

3. Rutgeerts P, Vermeire S, van Assche G. Biological therapies for inflammatory bowel diseases. Gastroenterology. 2009;136: $1182-1197$.

4. Grimm MC. New and emerging therapies for inflammatory bowel diseases. J Gastroenterol Hepatol. 2009;24(Suppl 3):S69-S74.

5. Atreya R, Neurath MF. New therapeutic strategies for treatment of inflammatory bowel disease. Mucosal Immunol. 2008;1:175-182.

6. Rogler G, Michetti P, Kruger F, et al. Active therapeutic immunization against TNF with a TNF-kinoid in Crohn's disease patients: a Phase 1-2 study. Gastroenterology. 2010;138(Suppl 1):517.

7. Engel MA, Neurath MF. New pathophysiological insights and modern treatment of IBD. J Gastroenterol. 2010;45:571-583.

8. Ito H, Takazoe M, Fukuda Y, et al. A pilot randomized trial of a human anti-interleukin-6 receptor monoclonal antibody in active crohn's disease. Gastroenterol. 2004;126(4):989-996.

9. Becker C, Fantini MC, Schramm C, et al. TGF-beta suppresses tumor progression in colon cancer by inhibition of IL-6 trans-signalling. Immunity. 2004;21:491-501.

10. Grivennikov S, Karin E, Terzic J, et al. IL-6 and stat3 are required for survival of intestinal epithelial cells and development of colitis associated cancer. Cancer Cell. 2009;15:103-113.

11. Lyakh L, Trinchieri G, Provezza L, et al. Regulation of interleukin12/interleukin-23 production and the T-helper 17 response in humans. Immunol Rev. 2008;226:112-131.

12. Neurath MF, Fuss I, Kelsall BL, et al. Antibodies to interleukin 12 abrogate established experimental colitis in mice. J Exp Med. 1995; 182:1281-1290.

13. Davidson NJ, Hudak SA, Lesley RE, et al. IL-12, but not IFN- $\gamma$, plays a major role in sustaining the chronic phase of colitis in IL-10 deficient mice. J Immunol. 1998;161:3143-3149.

14. Hue $\mathrm{S}$, Ahern $\mathrm{P}$, Buonocore $\mathrm{S}$, et al. Interleukin-23 drives innate and $\mathrm{T}$ cell mediated intestinal inflammation. J Exp Med. 2006;203:2473-2483.

15. Sandborn WJ, Feagan BJ, Fedorak RN, et al. Ustekinumab Crohn's Disease Study Group. A randomised trial of ustekinumab, a human interleukin-12/23 monoclonal antibody in patients with moderate to severe Crohn's disease. Gastroenterology. 2008;135:1130-1141.
16. Panaccione R, Sandborn W, Gordon G, et al. Briakinumab (ABT874) for treatment of Crohn's disease. Gut. 2010;59(Suppl 3):A11.

17. Waldner MJ, Neurath MF. Novel cytokine-targeted therapies and intestinal inflammation. Curr opin Pharm. 2009;9:702-707.

18. Danese S, Angelucci E, Malesci A, Caprilli R. Biological agents for ulcerative colitis: hypes and hopes. Med Res Rev. 2008;28(2); 201-218.

19. Reinisch W, Hommes DW, van Assche G, et al. A dose escalating, placebo controlled, double blind, single dose and multidose, safety and tolerability study of fontolizumab, a humanised anti-interferon gamma antibody, in patients with moderate to severe Crohn's disease. Gut. 2006;55:1138-1144.

20. Van Assche G, Dalle I, Noman M, et al. A pilot study on the use of the humanized anti-interleukin-2 receptor antibody daclizumab in active ulcerative colitis. Am J Gastroenterol. 2003;98:369-376.

21. Braat H, Rottiers P, Hommes DW, et al. A Phase I trial with transgenic bacteria expressing IL-10 in Crohn's disease. Clin Gastroenterol Hepatol. 2006;4:754-759.

22. Tilg $\mathrm{H}$, Vogelsang $\mathrm{H}$, Ludwiczek $\mathrm{O}$, et al. A randomised placebo controlled trial of pegylated interferon alpha in active ulcerative colitis. Gut. 2003;52:1728-1733.

23. Pena-Rossi C, Schreiber S, Golubovic G, et al. Clinical trial: a multicentre, randomised, double blind, placebo-controlled, dosefinding, phase II study of subcutaneous interferon-beta-la in moderately active ulcerative colitis. Ailiment Pharmacol Ther. 2008;28:758-767.

24. Siegmund B. Targeted therapies in inflammatory bowel disease. Dig Dis. 2009;27:465-469.

25. Soler D, Chapman T, Yang L, Wyant T, Egan R, Fedyk ER. The binding specificity and selective antagonism of vedolizumab, an anti- $\alpha 4 \beta 7$ integrin therapeutic antibody in development for inflammatory bowel diseases. J Pharmacol Exp Therap. 2009;330(3);864-875.

26. Hesterberg PE, Winsor-Hines D, Briskin MJ, et al. Rapid resolution of chronic colitis in the cotton-top tamarin with an antibody to the gut-homing integrin alpha 4 beta 7. Gastroenterology. 1996;111: 1373-1380.

27. Picarella D, Hurlbut P, Rottman J, Shi X, Butcher E, Ringler DJ. Monoclonal antibodies specific beta 7 integrin and mucosal addressin cell adhesion molecule-1 (MAdCAM-1) reduce inflammation in the colon of scid mice reconstituted with CD45RBhigh CD4+ T cells. J Immunol. 1997;158:2099-2106.

28. Lobb RR, Helmer ME. The pathophysiologic role of alpha 4 integrins in vivo. J Clin Invest. 1994;1722-1728.

29. Kleinschmidt-DeMasters BK, Tyler KL. Progressive multifocal leucoencephalopathy complicating treatment with natalizumab and interferon beta-1a for multiple sclerosis. N Eng J Med. 2005;353: 369-374.

30. Van Assche G, van Ranst M, Sciot R, et al. Progressive multifocal leucoencephalopathy after natalizumab therapy for Crohn's disease. N Eng J Med. 2005;353:362-368.

31. Butcher EC, Williams M, Youngman K, Rott L, Briskin M. Lymphocyte trafficking and regional immunity. Adv Immunol. 1999;72:209-253.

32. Salmi M, Jalkanen S. Lymphocyte homing to the gut; attraction, adhesion and commitment. Immunol Rev. 2005;206:100-113.

33. Feagan BG, Greenberg GR, Wild G, et al. treatment of ulcerative colitis with a humanised antibody to the alpha4beta7 integrin. $N$ Eng $J$ Med. 2005;352:2499-2507.

34. Feagan BG, Greenberg GR, Wild G, et al. Treatment of active Crohn's disease with MLN0002, a humanised antibody to the alpha4beta7 integrin. Clin Gastroenterol Hepatol. 2008;6:1370-1377.

35. Eksteen B, Adams DH. GSK-1605786, a selective small-molecule antagonist of the CCR9 chemokine receptor for the treatment of Crohn's disease. IDrugs. 2010;13(7):472-781.

36. Stronkhorst A, Radema S, Yong SL, et al. CD4 antibody treatment in patients with active Crohn's disease: a phase I dose finding study. Gut. 1997;40:320-327.

37. Mayer L. Evolving paradigms in the pathogenesis of IBD. J Gastroenterol. 2010;45:9-16. 
38. Van Assche G, Sandborn WJ, Feagan BG, et al. Daclizumab, a humanised monoclonal antibody to the interleukin 2 receptor $(\mathrm{CD} 25)$, for the treatment of moderately to severely active ulcerative colitis: a randomised, double blind, placebo controlled, dose ranging trial. Gut. 2006;55:1568-1574.

39. Hanauer S, Sandborn W, Sands BE, et al. A randomized placebo-controlled trial of Abatacept for moderately-to-severely active Crohn's disease. Gastroenterology. 2010;138(Supp 1):86.

40. Goetz M, Atreya R, Ghalibafian M, Galle PR, Neurath MF. Exacerbation of Ulcerative colitis following Rituximab salvage therapy. Inflamm Bowel Dis. 2007;13(11):1365-1368.

41. Schrezenmeir J, de Vreses M. Probiotics, prebiotics and synbioticsapproaching a definition. Am J Clin Nutr. 2001;73:361S-364S.

42. Sartor RB. Therapeutic manipulation of the enteric microflora in inflammatory bowel diseases: antibiotics, prebiotics and probiotics. Gastroenterology. 2004;126:1620-1633.

43. Roberfroid M. Prebiotics: the concept revisited. J Nutr. 2007;137: $830 \mathrm{~S}-837 \mathrm{~S}$

44. Kleessen B, Hartmann L, Blaut M. Oligofructose and long chain inulin: influence on the gut microbial ecology of rats associated with a human faecal flora. Br J Nutr. 2001;86:291-300.

45. Santos A, San MM, Diaz DM. Prebiotics and their long term influence on the microbial populations of the mouse bowel. Food Microbiol. 2006;23:498-503

46. Gibson GR, Beatty ER, Wang X, et al. Selective stimulation of bifidobacteria in the human colon by oligofructose and inulin. Gastroenterology. 1995;108:975-982.

47. Campbell JM, Fahey GC Jr, Wolf BW. Selected indigestible oligosaccharides affect large bowel mass, caecal and faecal short chain fatty acids, pH and microflora in rats. J Nutr. 1997;127:130-136.

48. Wong JM, de Souza R, Kendall CW, Emam A, Jenkins DJ. Colonic health: fermentation and short chain fatty acids. J Clin Gastroenterol. 2006;40:235-243.

49. Gionchetti P, Rizzello F, Helwig U, et al. Prophylaxis of pouchitis onset with probiotic therapy: a double blind, placebo controlled trial. Gastroenterology. 2003;124:1202-1209.

50. Mimura T, Rizzello F, Helwig U, et al. Once daily high dose probiotic therapy (VSL\#3) for maintaining remission in recurrent or refractory pouchitis. Gut. 2004;53:108-114.

51. Quigley EMM. Prebiotics and probiotics; modifying and mining the microbiota. Pharm Res. 2010;61:213-218.

52. Anderson RE, Olaison G, Tysk C, et al. Appendectomy and protection against ulcerative colitis. $N$ Eng J Med. 2001;344:808-814.

53. Derby LE, Jick H. Appendectomy protects against ulcerative colitis. Epidemiology. 1998;9:205-207.
54. Calkins BM. A meta-analysis of the role of smoking in inflammatory bowel disease. Dig Dis Sci. 1989;34:1841-1854.

55. Sonnenberg A, McCarty DJ, Jacobsen SJ. Geographic variation of inflammatory bowel disease within the united states. Gastroenterology. 1991;100:143-149.

56. Shivananda S, Lennard-Jones J, Logan R, et al. Incidence of inflammatory bowel disease across Europe: is there a difference between north and south? Results of the European Collaborative study on inflammatory bowel disease (EC-IBD). Gut. 1996;39:690-697.

57. Weinstock JV, Elliott DE. Helminths and the IBD hygiene hypothesis Inflamm Bowel Dis. 2009;15:128-133.

58. Khan WI, Blennerhasset PA, Varghese AK, et al. Intestinal nematode infection ameliorates experimental colitis in mice. Infect Immun. 2002; 70:5931-5937.

59. Moreels TG, Nieuwendijk RJ, de Man JG, et al. Concurrent infection with schistosoma mansoni attenuates inflammation induced changes in colonic morphology, cytokine levels and smooth muscle contractility of trinitrobenzene sulphonic acid induced colitis in rats. Gut. 2004;53: 99-107.

60. Summers RW, Elliot DE, Urban JF Jr, et al. Trichuris suis therapy in Crohn's disease. Gut. 2005;54:87-90.

61. Summers RW, Elliot DE, Urban JF Jr, et al. Trichuris suis therapy for active ulcerative colitis: a randomised controlled trial. Gastroenterology. 2005;128:825-832.

62. Mitsuyama K, Sata M. Therapeutic leukocytapheresis in inflammatory bowel disease: clinical efficacy and mechanisms of action. Ex Cytotherapy. 2009;11(2):229-237.

63. Arseneau KO, Cominelli F. Leukocytapheresis in ulcerative colitis: a possible alternative to biological therapy? Dig Liver Dis. 2009;41 551-552.

64. Sands BE, Sandborn WJ, Feagan B, et al. A randomized, double-blind, sham controlled study of granulocyte/monocyte apheresis for active ulcerative colitis. Gastroenterology. 2008;135:400-409.

65. Godoi DF, Cardoso CR, Ferraz DB, et al. Hemopoietic SCT modulates gut inflammation in experimental inflammatory bowel disease. Bone Marrow Trans. 2010:1-10.

66. Oyama Y, Craig RM, Traynor AE, et al. Autologous hematopoietic stem cell transplantation in patients with refractory Crohn's disease. Gastroenterology. 2005;128(3):552-563.

67. Prantera C, Lochs H, Gionchetti P, et al. Rifaximin-EIR $400 \mathrm{mg}$ tablets in the treatment of moderately active Crohn's disease: results of the International, multicentre, randomized, double-blind, placebocontrolled trial RETIC-03. Gut. 2010;59(Suppl 3):A1.
Journal of Experimental Pharmacology

\section{Publish your work in this journal}

The Journal of Experimental Pharmacology is an international, peerreviewed, open access journal publishing original research, reports, reviews and commentaries on all areas of laboratory and experimental pharmacology. The manuscript management system is completely online and includes a very quick and fair peer-review system.

\section{Dovepress}

Visit http://www.dovepress.com/testimonials.php to read real quotes from published authors. 